\title{
Renal capsulotomy associated with omentopexy for treatment of bilateral perinephric abscess in a bitch: case report
}

\section{Capsulotomia renal associada à omentopexia para tratamento de abcesso perirrenal bilateral em uma cadela: relato de caso}

\author{
Rogério Luizari Guedes ${ }^{1 *}$; Peterson Triches Dornbusch ${ }^{2}$; Bruna Natali Costa ${ }^{3}$; \\ Tilde Rodrigues Froes ${ }^{2}$; Marlos Gonçalves Sousa ${ }^{2}$; Simone Tostes Oliveira²
}

\begin{abstract}
A perinephric abscess is a rare and difficult to treat disease in veterinary medicine. The aim of this paper is to report a case of successful treatment using capsulotomy and omentopexy for bilateral perinephric abscess in a dog.
\end{abstract}

Key words: Kidney. Surgery. Pus.

\section{Resumo}

\begin{abstract}
Abscesso perinéfrico é uma condição rara na medicina veterinária e de difícil tratamento. O objetivo deste trabalho é relatar um caso de sucesso no tratamento de abscesso perinéfrico bilateral em um cão, usando capsulotomia e omentopexia.
\end{abstract}

Palavras-chave: Rim. Cirurgia. Pús.

\section{Introduction}

A perinephric abscess occurs as a complication of an ascending urinary tract infection or systemic infection (HUTCHISON; KAYSEN, 1988). It is rare in veterinary medicine and is usually unilateral in dogs and cats (AGUT et al., 2004; ZATELLI; D'IPPOLITO, 2004). Antibiotic treatment has not been very effective, and surgical treatment or percutaneous aspiration under ultrasound guidance have shown better results (HUTCHISON; KAYSEN, 1988). Nephrectomy is therefore indicated for the most complex cases (LEWIS et al., 1988; AGUT et al., 2004). Omentalization as complementary treatment for abscesses and wound healing are reported for abdominal structures (CAMPBELL, 2004; JOHNSON; MANN, 2006; FREITAG et al., 2007; CASE; ELLISON, 2013), but still not described for kidneys. The long-term prognosis of the disease is poor (AGUT et al., 2004). This report describes a case of successful treatment using capsulotomy with omentopexy, avoiding ureteronephrectomy, to treat bilateral perinephric abscesses in a bitch.

1 Prof. Adjunto, Universidade Tuiuti do Paraná, UTP/PR, Curitiba, PR, Brasil. E-mail: rogerioguedes@veterinario.med.br

2 Profs., Programa de Pós-Graduação em Ciências Veterinárias da Universidade Federal do Paraná, PPGCV/UFPR, Curitiba, PR, Brasil. E-mail: petriches@gmail.com; froestilde@gmail.com; marlos98@yahoo.com; tostesimone@gmail.com

3 Discente, Programa de Residência Multidisciplinar em Medicina Veterinária, UFPR, Curitiba, PR, Brasil. E-mail: bruh.naty@ hotmail.com

* Author for correspondence 


\section{Case report}

A 13-year-old non-castrated mongrel bitch, weighing $27 \mathrm{~kg}$ was examined for signs of polyuria, polydipsia, anorexia and weakness. On initial evaluation, mild fever was noted (rectal temperature $39.7^{\circ} \mathrm{C}$ ), as well as dehydration $(7 \%)$ and a body condition score of 3/9. Abdominal palpation elicited pain. The dog also had skin lesions and showed signs of flea allergic dermatitis and pododermatitis. The complete blood count revealed leukocytosis $\left(27,000 \mathrm{uL}^{-1}\right)$ with neutrophilia $\left(22,848 \mathrm{uL}^{-1}\right)$, eosinophilia $\left(1,360 \mathrm{uL}^{-1}\right)$ and monocytosis $(1,904$ $\left.\mathrm{uL}^{-1}\right)$. There was also hyperproteinemia $(8.5 \mathrm{~g}$ $\left.\mathrm{dL}^{-1}\right)$ with hyperglobulinemia $\left(6.6 \mathrm{mg} \mathrm{dL}^{-1}\right)$ and hypoalbuminemia $\left(1.9 \mathrm{~g} \mathrm{dL}^{-1}\right)$. Blood urea nitrogen and creatinine were normal, but an increase in the urinary protein:creatinine ratio (1.4) was observed. Urinalysis showed a low specific density (1.012) and an absence of glycosuria, pyuria or bacteriuria. Abdominal ultrasonography revealed hypoechoic and septate hyperechoic bands and debris in the subcapsular region in the left and right kidneys. The cortex of the kidneys was diffusely hyperechoic however, with normal corticomedullar distention. The subcapsular effusion indicated perinephric renal abscesses (Figure 1). During examination, 25 and $10 \mathrm{~mL}$ were tapped from the left and right perinephric abscesses, respectively; samples were sent for cytological analyses, culturing and antibiotic sensitivity tests. Cytological analyses showed inflammation. Profuse growth of Staphylococcus pseudintermedius occurred in culture, which was sensible to all antibiotics tested. Urine was also evaluated by culturing and antibiograms, showing negative results.

Figure 1. Ultrasonographic image of the left kidney showing renal hypoechoic fluid (arrow) with septate hyperechoic bands and debris in the subcapsular region - perinephic abscess. The renal cortex was diffusely hyperechoic.

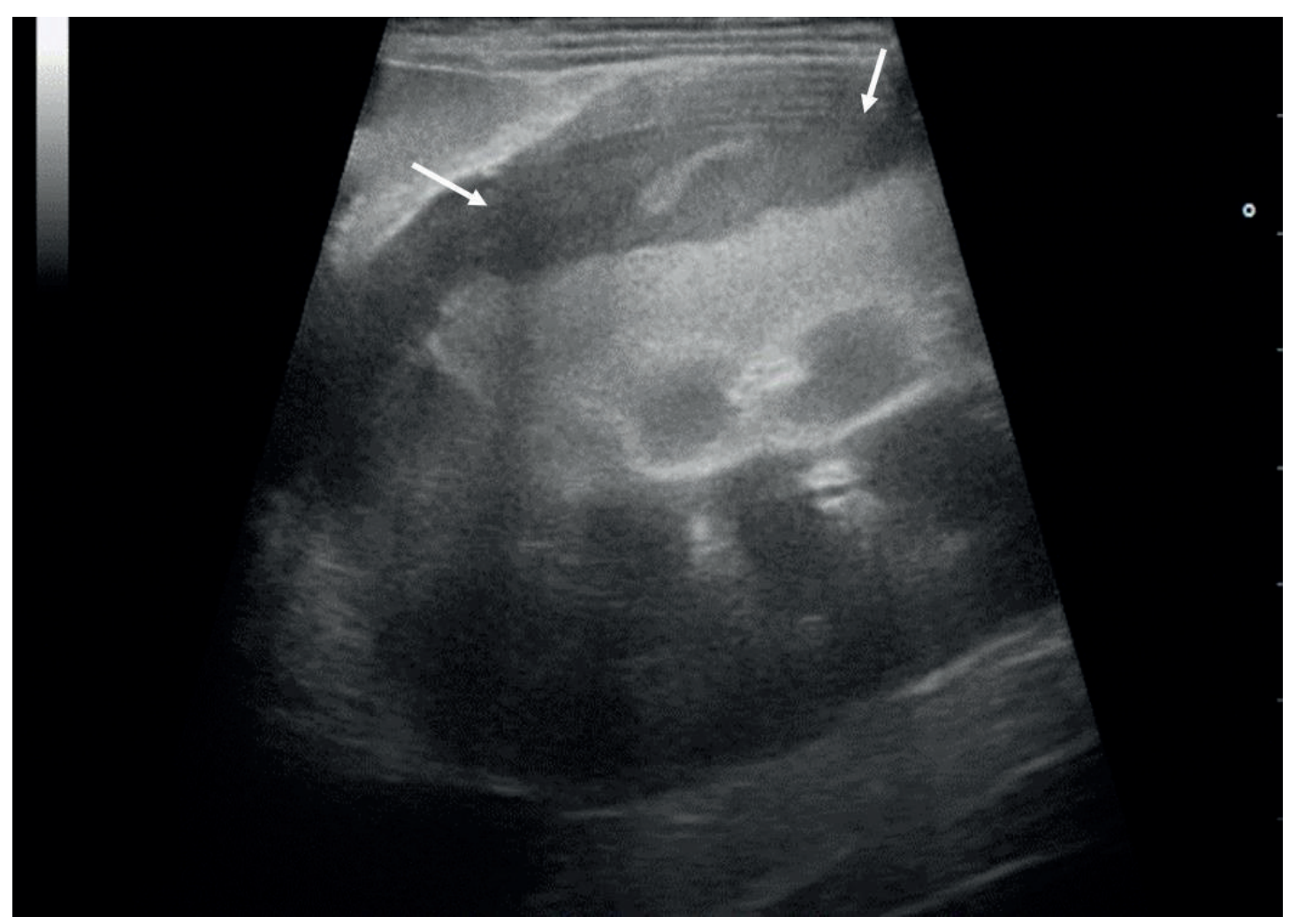


Newly accumulated effusion was detected by ultrasonography ten days after drainage. An exploratory celiotomy was indicated, with the patient was positioned in dorsal recumbency for pre-retro umbilical access. Abdominal cavity exploration disclosed no significant changes in other organs nor the presence of effusions. After locating the right kidney, it was exposed by dissecting the retroperitoneal space. Besides nephromegaly, an opaque and thick capsule with petechiae was noted. A small capsulotomy was performed with monopolar electrocautery, allowing identification of the exudate and aspiration of all content. On completion of the capsulotomy, evaluation of the superficial renal parenchyma revealed depressions, but otherwise signs of fistulae and ruptures were absent. A copious lavage with saline solution in a 10 $\mathrm{mL}$ syringe fitted with a hypodermic needle $(25 \mathrm{x} 7$ $\mathrm{mm}$ ) was performed. Then, the capsule margins were resected and an omentum flap was positioned over the renal surface, and attached to the remaining capsule with a 3-0 polyglactin 910 thread and an atraumatic needle $(1,0 \mathrm{~cm}, 1 / 2$ circle), using simple interrupted patterns. (Figure 2). Similar alterations were noted in the left kidney and the same procedure was performed. The abdominal cavity was flushed with warm saline solution followed by application of a silicon abdominal drain (20Fr), and celiorraphy was performed as usual.

Figure 2. (A) Distended renal capsule due to perinephric abscess in a dog. (B) Aspect of the capsule after drainage using a syringe and needle, followed by capsulotomy. (C) Omentum flap positioned over the renal surface. (D) Omentopexy completed.
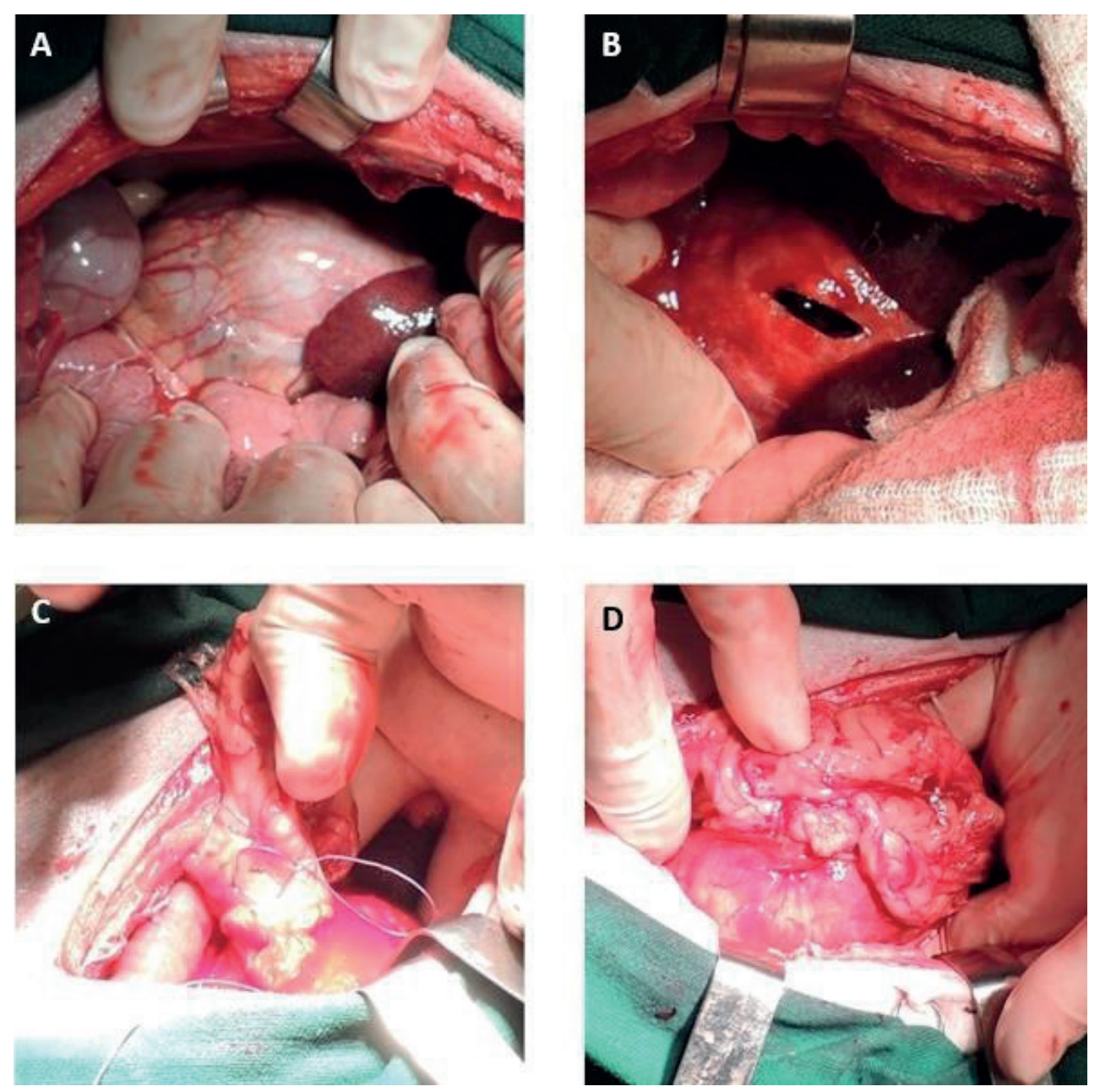

Semina: Ciências Agrárias, Londrina, v. 39, n. 5, p. 2301-2306, set./out. 2018 
The patient remained hospitalized for 12 days. Postoperative medication consisted in antibiotics (amoxicillin + clavulanic acid), an antiemetic (metoclopramide), gastric protectors (ranitidine cloridrate, omeprazole), and analgesics (hyoscine, dipyone, tramadol cloridrate). Bandaging and cleaning of the abdominal drain was performed with saline solution for three days until no discharge secretion was noted. The drain was then removed and healing was performed by second intention. Sixteen days after the procedure, serial ultrasonography exams revealed only a hyperechoic bilateral capsule distension without subcapsular content, which was consistent with no more fluid accumulation in the subcapsular area of both kidneys. A month later, the images were normal, suggesting the remission of the abscesses; the patient had gained weight, was clinically stable and had a normal appetite. After five months, all repeated tests showed no abnormalities, including urinalysis, in which the specific density increased to 1.050. The bitch has been followed up for 18 months after surgery, and shows no sign of urinary tract diseases.

\section{Discussion}

The treatment using capsulotomy followed by omentopexy had a positive outcome, since there were no complications and the patient remained healthy. This procedure was effective in preserving both kidneys; omentopexy contributed to drainage and healing. Most of the literature describes cases with unilateral perinephric abscess, which required nephrectomy as treatment (LEWIS et al., 1988; AGUT et al., 2004).

Two cases describing bilateral perinephric abscess in dogs also had multiple renal bilateral cysts and culture was positive for Escherichia coli (KITSHOFF et al., 2011; PINTO FILHO et al., 2013). Unexpectedly, in the present case the culture was positive for Staphylococcus pseudintermedius, which is commonly found in skin lesions. This fact, associated with the sterile urine, suggests that the infection occurred systemically, from skin to blood and kidneys, probably due to the observed skin lesions. One case in the literature describes a dog with systemic inflammatory response syndrome induced by bacterial dermatitis due to S. pseudintermedius (MIN et al., 2014). Finally, in contrast to other cases where dogs had perinephric abscesses associated with renal cysts (KITSHOFF et al., 2011; PINTO FILHO et al., 2013), in this report the dog had perinephric abscesses without renal cysts; this likely improved the prognosis and recovery.

The most common causes of perinephric abscess are nephrolithiasis, obstruction of the urinary tract, or cystitis suggesting an ascending urinary tract infection (HUTCHISON; KAYSEN, 1988; AGUT et al., 2004). Although none of these diseases were noted, some signs of kidney disease, such as a high protein:creatinine ratio and isosthenuria were present, probably as a consequence of the inflammation. These signs also disappeared after surgery and antibiotic treatment. Similar to the animal in our report, dogs described in the literature (LEWIS et al., 1988; AGUT et al., 2004; KITSHOFF et al., 2011; PINTO FILHO et al., 2013) also presented some clinical signs, even if they were unspecific. Such signs include loss of appetite, fever, depression, and abdominal pain. Early diagnosis is important to avoid irreversible damage to the kidneys, and for the infection to be eliminated through surgery and drainage, since conservative treatment using only antibiotics has demonstrated a worse prognosis (HUTCHISON; KAYSEN, 1988; KITSHOFF et al., 2011).

\section{Conclusion}

The surgical procedure using capsulotomy with omentopexy to drain bilateral perinephric abscesses was effective in this bitch, allowing both kidneys to be preserved. 


\section{References}

AGUT, A.; LAREDO, F. G.; BELDA, E.; SEVA, J.; SOLER, M. Left perinephric abscess associated with nephrolithiasis and bladder calculi in a bitch. Veterinary Record, London, v. 154, n. 18, p. 562-565, 2004.

CAMPBELL, B. G. Omentalization of a nonresectable uterine stump abscess in a dog. Journal of the American Veterinary Medical Association, Schaumburg, v. 224, n. 1, p. 1799-1803, 2004.

CASE, J. B.; ELLISON, G. Single incision laparoscopicassisted intestinal surgery (SILAIS) in 7 dogs and 1 cat. Veterinary Surgery, Hoboken, v. 42, n. 5, p. 629-634, 2013.

FREITAG, T.; JERRAM, R. M.; WALKER, A. M.; WARMAN, C. G. Surgical management of common canine prostatic conditions. Compendium: Continuing Education for Veterinarians, Bethesda, v. 29, n. 11, p. 656-658, 2007.

HUTCHISON, F. N.; KAYSEN, G. A. Perinephric abscess: the missed diagnosis. Medical Clinics of North America, London, v. 72, n. 5, p. 993-1014, 1988.

JOHNSON, M. D.; MANN, F. A. Treatment for pancreatic abscesses via omentalization with abdominal closure versus open peritoneal drainage in dogs: 15 cases (1994-2004). Journal of the American Veterinary Medical Association, Schaumburg, v. 228, n. 3, p. 397402, 2006.
KITSHOFF, A. M.; MCCLURE, V.; LIM, C. K.; KIRBERGER, R. M. Bilateral multiple cystic kidney disease and renal cortical abscess in a Boerboel. Journal of the South African Veterinary Association, Pretoria, v. 82, n. 2, p. 120-124, 2011.

LEWIS, D. C.; ADAMSON, D. R.; JACOBS, K. A.; LAMB, W. A. Pyelonephritis, nephrolithiasis and perinephric abscessation in a dog. Australian Veterinary Journal, Sidney, v. 65, n. 6, p. 195-196, 1988.

MIN, S. H.; KANG, M. H.; SUR, J. H.; PARK, H. M. Staphylococcus pseudintermedius infection associated with nodular skin lesions and systemic inflammatory response syndrome in a dog. Canadian Veterinary Journal, Guelph, v. 55, n. 5, p. 480-483, 2014.

PINTO FILHO, S. T. L.; BRUN, M. V.; DALMOLIN, F.; HARTMANN, H.; PEREIRA, D. T.; POHL, V. H.; COUTINHO JÚNIOR, A. S.; GIGLIO, C. F.; WIECHETECK, F. S.; OLIVEIRA, M. T.; GODOY, C. L. B.; HORA, A. M. Ressecção de cisto e abscesso renais por laparoscopia em um cão. Arquivo Brasileiro de Medicina Veterinária e Zootecnia, Belo Horizonte, v. 65, n. 6, p. 1651-1656, 2013.

ZATELLI, A.; D'IPPOLITO, P. Bilateral perirenal abscesses in a domestic neutered shorthair cat. Journal of Veterinary Internal Medicine, Greenwood Village, v. 18, n. 6, p. 902-903, 2004. 
